音声言語医学 $39: 5-8,1998$

原著

\title{
術後唇顎口蓋裂児における構音障害の有無と言語発達
}

\author{
中嶋 敏子
}

要 約：異常構音が存在するために構音訓練の開始を予定している唇䫟口蓋裂群と構音訓練 を必要とする異常構音は存在しないと判定された唇顎口蓋裂群および正常児群の 3 群に WPPSI 知能診断検査を行い，3群間に差がみられるか検討した。

その結果, 3 群とも言語性知能指数 (以下, VIQ) が動作性知能指数 (以下, PIQ) より有意

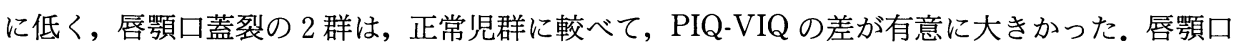
蓋裂の 2 群間に差はなかった。

正常児群に較べて, 唇顎口蓋裂児群 2 群の PIQ-VIQ の差が有意に大きいという結果によっ て, 唇頡口蓋裂児群 2 群に構音に限らない言語発達の遅れがあることが示唆された。

索引用語: 唇顎口蓋裂, $4 \sim 5$ 歳, WPPSI 知能診断検査, 構音障害

\section{Relationship between Language Development and Articulation Disorders in Children with Repaired Clefts of Lip and Palate}

\section{Toshiko Nakajima}

\begin{abstract}
We compared the results of the Wechsler Preschool and Primary Scale of Intelligence (WPPSI) among three groups of $4 \sim 5$ year old children. Group $1(n=43)$ and Group $2(n=20)$ consisted of children with repaired clefts of the lip and palate. Group 1 needed articulaion treatment but Group 2 did not. Group $3(n=32)$ was a control group. Children who had other complications were excluded. Also, subjects were restricted to children whose Performance Intelligence Quotient (PIQ) was 80 or more. The mean Verbal Intelligence Quotient (VIQ) was significantly lower than the PIQ in all groups. Also, the mean difference between VIQ and PIQ was significantly larger in Groups 1 and 2 than in Group 3 . There were no significant differences between the two cleft palate groups. These results indicate that the two cleft palate groups have some common problems of language development which are causing the large VIQ-PIQ difference.
\end{abstract}

Key words : cleft of lip and palate, $4 \sim 5$ years old, WPPSI, articulation disorders 


\section{はじめに}

われわれは, 手術成績が良く, 生後早期からの定期 検査において, 正常な構音発達の道筋を辿っていると 言語治療士によって判定されてきた 4 歳代の唇枵鿓口 裂児の構音発達が， $/ \mathrm{k}, \mathrm{s}, \mathrm{r} /$ 音において遅れてい るという知見を先に報告した ${ }^{11}$.

唇頡口蓋裂児の言語発達が，構音においてのみ遅れ るのか, 語彙や構文においても遅れるのか知見を得る ことは，口蓋裂児および家族の指導を行う上で重要で ある。われわれは, 口蓋裂児が 4,5 歳代に達すると WPPSI 知能診断検査を行い, 発達の状況を分析し, 本 人や家族の指導に活用している.

言語発達に関与する合併症のない唇䋶口蓋裂児の Wechsler 法による知能検查結果については, Lamb $ら^{2)}$ と McWilliams ら ${ }^{3)}$ の調査報告がある。前者は，唇 顎口蓋裂児の言語性知能指数 (以下, VIQ) は動作性知 能指数 (以下, $\mathrm{PIQ}$ ) より有意に低かったと報告し, 後 者は有意な差はみられなかったと報告している。

本研究では, 知的発達が正常と思われる唇顎口蓋裂 児と正常児とで WPPSI 知能診断検査の VIQ および $\mathrm{PIQ}$ と VIQ との乘離に差があるか, そして, 構音訓練 を必要とした異常構音の存在が結果に影響を与えるか 検討するために，構音訓練が必要と判断された唇頜口 蓋裂群と不要と判断された唇䂓口蓋裂群および正常群 にWPPSI 知能診断検査を行い結果を比較した。

\section{対象および方法}

対象は生後早期から当科で言語管理を受けている術 後の唇靧口蓋裂 63 例と対照 32 例であり, 全例 $4 \sim 5$ 歳である. 唇顎口蓋裂症例を構音訓練が必要であった か否かによって，2 群に分けた。第 1 群（43 例）は,
構音訓練を必要とした唇顎口蓋裂児で構成されてい る. 通常の発達の過程ではみられない非典型的な構音 の誤りが出現し, 発達とともに自然に改善しなかった ので構音訓練が必要と判定し, 構音訓練が計画されて いた。第 2 群（20 例）は，構音訓練を必要としないと 判定した唇顎口蓋裂児である.第 1 群の男児 10 例と女 児 2 例および第 2 群の男児 2 例は両側唇顎口蓋裂であ り, 他は片側性唇顎口蓋裂である. 全例, 当院の形成 外科で口唇形成術ならびに口蓋形成術を受け, 大半の 症例が, 術後, 良好な鼻咽腔閉鎖機能を獲得したが, 第 1 群の 12 例および第 2 群の 5 例は再手術を必要と した. 調査対象は, PIQ が 80 以上のものに限った. 言 語発達に関与する可能性のある合併症を持つ例は, 調 査対象より除外した。

被検児に関するその他のデーターは表 1 に示す。著 者を含んだ 4 人の言語治療士が, WPPSI 知能診断検 查を実施した。統計処理には, $\mathrm{t}$ 検定, 共分散分析法な らびにSASを採用した。

\section{結果}

WPPSI 知能診断検査の結果を表 2 に示す. 全群に おいて, $\mathrm{VIQ}$ の平均は, $\mathrm{PIQ}$ の平均より $\mathrm{t}$ 検定にて有 意に低かった. VIQ-PIQ 間の差の平均は, 第 3 群に 較べて, 第 1 群および第 2 群が大きく, 第 1 群と第 3 群間および第 2 群と第 3 群間の差は統計的に有意であ った。口蓋裂の 2 群間には, 有意な差はなかった.VIQ 対 PIQ の共分散分析法にて, 第 2 群と第 3 群間で有意 差がみられた $(\mathrm{p}<0.036)$. 第 1 群と第 3 群間で差があ る傾向がみられたが, 統計的には有意ではなかった $(\mathrm{p}<0.063)$. 第 1 群と第 2 群間では有意な差はなかっ た. IQ, VIQ, PIQ の相関を表 3 に示す. $\mathrm{r}$ 值は, IQ と VIQ 間で最大で，VIQ と PIQ 間で最小であった。ま

表 1 被検児

\begin{tabular}{|c|c|c|c|c|c|c|c|c|c|c|c|c|}
\hline & & \multicolumn{3}{|c|}{1 群 } & \multicolumn{4}{|c|}{2 群 } & \multicolumn{4}{|c|}{ 対照群 } \\
\hline \multirow[t]{3}{*}{ 例数 } & 計 & 43 例 & （男 27 . & 女 16) & 20 例 & （男 1 & 10. & 女 10) & 32 例 & （男 & 17. & 女 15) \\
\hline & 4 歳代 & 28 & ( 17 . & 11) & 11 & ( & 4. & 7) & 16 & ( & 8. & 8) \\
\hline & 5 歳代 & 15 & $(10$. & 5) & 9 & ( & 6. & 3) & 16 & ( & 8. & 8) \\
\hline \multirow[t]{2}{*}{ 口唇形成術時月齢 } & 平均土標準偏差 & \multicolumn{3}{|c|}{$4.0 \pm 1.8$} & \multicolumn{8}{|c|}{$3.0 \pm 0.8$} \\
\hline & 範囲 & \multicolumn{3}{|c|}{$2 \sim 14$} & \multicolumn{8}{|c|}{$3 \sim 5$} \\
\hline \multirow[t]{2}{*}{ 口蓋形成術時月齢 } & 平均土標準偏差 & \multicolumn{3}{|c|}{$13.0 \pm 3.7$} & \multicolumn{8}{|c|}{$13.0 \pm 1.8$} \\
\hline & 範囲 & \multicolumn{3}{|c|}{$3 \sim 33$} & \multicolumn{8}{|c|}{$11 \sim 17$} \\
\hline \multirow[t]{2}{*}{ WPPSI 実施時月齢 } & 平均土標準偏差 & \multicolumn{3}{|c|}{$56 \pm 5.9$} & \multicolumn{4}{|c|}{$59.0 \pm 4.7$} & \multicolumn{4}{|c|}{$58.0 \pm 6.8$} \\
\hline & 範囲 & \multicolumn{3}{|c|}{$48 \sim 70$} & \multicolumn{4}{|c|}{$52 \sim 62$} & \multicolumn{4}{|c|}{$48 \sim 70$} \\
\hline
\end{tabular}


表 2 WPPSI 知能診断検査の結果

\begin{tabular}{llllll}
\hline & & 1 群 & 2 群 & 対照群 & 群間の差 \\
\hline IQ & 平均士標準偏差 & $98.6 \pm 18.0$ & $97.9 \pm 18.3$ & $100.1 \pm 14.4$ & \\
& 範囲 & $59 \sim 147$ & $61 \sim 132$ & $69 \sim 133$ & \\
VIQ & 平均士標準偏差 & $90.4 \pm 20.7$ & $89.2 \pm 17.7$ & $96.0 \pm 15.3$ & \\
& 簿囲 & $59 \sim 142$ & $57 \sim 122$ & $66 \sim 125$ & \\
PIQ & 平均士標準偏差 & $108.1 \pm 13.9$ & $108.0 \pm 16.4$ & $104.6 \pm 12.6$ & \\
& 範囲 & $89 \sim 150$ & $80 \sim 138$ & $80 \sim 130$ & \\
VIQ-PIQ 差 & 平均士標準偏差 & $-17.7 \pm 19.7$ & $-18.8 \pm 15.7$ & $-8.5 \pm 14.7$ & 1 群と対照群間, \\
& 範囲 & $-49 \sim 21$ & $-60 \sim 6$ & $-33 \sim 25$ & 2 群と対照群間 \\
& & & & & $\mathrm{P}<0.05$ \\
\hline 有意差 & $\mathrm{VIQ}, \mathrm{PIQ}$ 間 & $\mathrm{p}<0.001$ & $\mathrm{p}<0.005$ & $\mathrm{P}<0.025$ & \\
& $\mathrm{IQ}, \mathrm{PIQ}$ 間 & $\mathrm{P}<0.01$ & & & \\
\hline 言語性検查評価点 & & & & & \\
知識 & & 9.0 & 8.9 & 10.1 & \\
単語 & & 8.4 & 8.5 & 9.3 & \\
算数 & & 9.2 & 8.8 & 9.3 & \\
類似 & & 7.9 & 7.7 & 8.4 & \\
理解 & & 8.8 & 8.5 & 9.9 & \\
\hline
\end{tabular}

表 3 IQ，VIQ，PIQ 間の相関係数 ( $\mathrm{r}$ 値)

\begin{tabular}{lcccc}
\hline & 1 群 & 2 群 & 対照群 \\
\hline IQ, VIQ 間 & $0.91(\mathrm{p}<0.001)$ & $0.90(\mathrm{P}<0.001)$ & $0.89(\mathrm{P}<0.001)$ \\
IQ, PIQ 間 & $0.74(\mathrm{p}<0.001)$ & $0.87(\mathrm{p}<0.001)$ & $0.81(\mathrm{P}<0.001)$ \\
VIQ, PIQ 間 & $0.41(\mathrm{P}<0.007)$ & $0.58(\mathrm{p}<0.007)$ & $0.46(\mathrm{P}<0.008)$ \\
\hline
\end{tabular}

た, 第 1 群において, IQ と $\mathrm{PIQ}$ 間に有意差がみられ た。言語性検査の下位検査の評価点について, 群間の 差はなかった。なお，今回の調査において，被検児に 異常構音があるために回答を検者が聞いて理解できな いということは生じなかった。

\section{考察}

構音訓練を必要とする異常構音の有無は, 唇顎口蓋 裂 2 群の WPPSI 知能診断検査の結果に統計上有意な 差を生じなかった。

唇效口蓋裂の 2 群と対照群間で差があったことは, 唇顎口蓋裂の 2 群に構音面にとどまらない言語発達の 遅れがあることを示唆している．言語発達に影響しう る合併症を持たない口蓋裂児のみを調査対象としたい

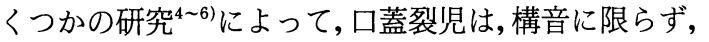
語彙, 発話の長さ, 構文等発語の他の側面にも発達の 遅れが認められたと報告されている.本研究の結果は, これらの先行研究の結果を支持すると考えられる.
口蓋裂児の言語発達を遅れさせる原因として先ず考 えられるのは, 発語器官の形態の異常である.

外科的手術で口蓋の形態と機能が修復された後も口 蓋裂児の構音発達が遅れることは，口蓋形成術前およ び術後の構音発達に関する研究7,8)やわれわれの研究1) でもすでに指摘されているが，構音発達の問題が表出

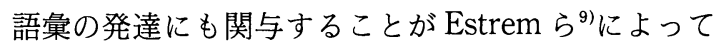
示唆されている。

前述したように，口蓋裂児の言語発達を遅らせる第 一の要因は, 出生時から存在する発語器官の構造の異 常であると思われるが，そのことに由来して，適切な 強化刺激が与えにくかったことも関与している可能性 も否定できない. Laine $ら^{10)}$ は, 実験によって口腔内圧 が減少すると, 鼻腔内圧は増加し, 口腔内圧と鼻腔内 圧の和は一定に保たれることを確認した。口蓋未手術 で鼻咽腔閉鎖機能不全の条件下では，Laine $ら^{10)}$ が確 認した調節機構が働くことにより，産生される語音の 鼻性度が増強され，非通鼻音の産生が困難である。こ 
のように, 発語器官の構造の異常に起因して, 口蓋裂 児の発達初期の喃語や有意味語の音が非口蓋裂児と異 なった特性を持つ怆めに, 養育者が口蓋裂児の発声 や発語に気付きにくく, その結果, 発声や発語に対す る適切な強化刺激を与えることが十分になされていな いという報告 ${ }^{11,12) か ゙ あ る . ~}$

発語器官の構造そのものに起因する言語発達の遅れ については口蓋形成術の実施時期と術式の検討が必要 であるが, 言語発達初期の口蓋裂児の発声, 発語に対 する適切な強化刺激の与え方や動機づけの仕方ならび に話すことに充足感を与え, 自信をつけることについ ては，母親教室を初めとして生後早期から行っている 言語管理の内容を検討すべきであろう.

本調査では, 表 2 に示すようにすべての群において 成績のばらつきが大きかった. Wechsler による同様 の検査である Wechsler Intelligence Scale for Children（以下，WISC 知能診断検査）の標準化では， 5 〜 15 歳の 11 の年齢段階の 200 例ずつに検査を行って いるが, VIQ と PIQ の乘離の範囲は, +36 から -36 で あり, 標準偏差の範囲も 11.9 から 14.7 と大きかっ $た^{13)}$. それよりさらに本調査の方がばらつきが大きか ったのは, 被検者の数の少なさも影響していると考え られる. 本調査において, 3 群とも PIQ が VIQ より有 意に大きかった。この結果が WISC 知能診断検査の標 準化において示唆されたように, 社会経済的階層によ る特性なのか否かについては，また稿を改めて検討す る必要がある。

稿を終えるにあたり,ご指導ならびにご閱読下さった福岡大学 医学部小児科学教室名誉教授小田禎一先生, 教授満留昭久先生, ご助言を下さった上智大学岡崎恵子先生, 福岡市立心身障害福祉 センター耳鼻咽喉科石澤博子先生, 英語学的ご助言を下った聖マ リア学院短期大学助教授 Raynald Noreau 先生, 資料の段階でお 世話になった聖マリア病院形成外科部長吉川厚重先生, 言語治療 科乾智子, 西山栄子, 小島博子先生, 聖マリア保育所, 高取保育 所, 若草幼稚園の先生方, 西山正代さんに深謝する.

本稿の一部は, 第 41 回日本音声言語医学会総会において発表 した.

\section{文献}

1）中嶋敏子：口蓋裂手術後 4 歳児における構音発達 の遅れに関する研究. 福岡大学医学紀要, $23: 117$ $-121,1996$.

2) Lamb, M. M., Wilson, F. B., Leeper H. A. : The intellectual function of cleft palate children compared on the basis of cleft type and sex. Cleft Palate J., 10: 367-377, 1973.

3) McWilliams, B. J., Matthews, H. P. : A comparison of intelligence and social maturity in children with unilateral complete clefts and those with isolated cleft palates. Cleft Palate J., 16 : 363-372, 1979.

4) Spriestersbach, D. C., Darley, F. D., Morris, H. L. : Language skills in children with cleft palates. Journal of Speech and Hearing Research, $1: 279-285,1958$.

5) Nation, J. E. : Vocabulary comprehension and usage of preschool cleft palate and normal children. Cleft Palate J., 7 : 639-644, 1976.

6）村上敏子, 鈴木智子, 岡崎恵子 : 口蓋裂児の言語 発達. 音声言語医学, $26: 105-106,1985$.

7) Chapman, K. L. : Vocalization of toddlers with cleft lip and palate. Cleft Palate-Craniofacial J., $28: 172-178: 1991$.

8) O'Gara, M. M., Logemann, J. A. : Phonetic analysis of the speech development of babies with cleft palate. Cleft Palate J., 25 : 122-134, 1988 .

9) Estrem, T., Broen P. A. : Early speech production of children with cleft palate. : Journal of Speech and Hearing Research, 32 : 12-23, 1989.

10) Laine, T., Warren, D., Dalston, R., et al. : Intraoral pressure, nasal pressure and air flow rate in cleft palate speech. Journal of Speech and Hearing Research, $31:$ 432-437, 1988.

11) Chapman, K. L., Hardin, M. A. : Language input of mothers interacting with their young children with cleft lip and palate. Cleft Palate J., 28 : 78-86, 1991.

12) Philips, B. J., Harrison, R. J. : Language skills of preschool cleft palate children. Cleft Palate J., $6: 108-119,1969$.

13) Seashore, H. G. : Differences between verbal and performance IQs on the Wechsler Intelligence Scale for Children. J. Consult Psychol., 15: 62-67, 1951.

別刷請求先: $\bar{\top} 830$ 久留米市津福本町 422 聖マリア病院言語治療科 中嶋敏子 